\title{
Quantification of iron-rich volcanogenic dust emissions and deposition over the ocean from Icelandic dust sources
}

\author{
O. Arnalds ${ }^{1}$, H. Olafsson ${ }^{2,3,4}$, and P. Dagsson-Waldhauserova ${ }^{1,2}$ \\ ${ }^{1}$ Agricultural University of Iceland, Hvanneyri, 311 Borgarnes, Iceland \\ ${ }^{2}$ University of Iceland, Reykjavik, Iceland \\ ${ }^{3}$ The Icelandic Meteorological Office, Reykjavik, Iceland \\ ${ }^{4}$ Bergen School of Meteorology, Geophysical Institute, University of Bergen, Bergen, Norway \\ Correspondence to: O. Arnalds (oa@lbhi.is)
}

Received: 27 February 2014 - Published in Biogeosciences Discuss.: 28 April 2014

Revised: 2 September 2014 - Accepted: 29 October 2014 - Published: 2 December 2014

\begin{abstract}
Iceland has extremely active dust sources that result in large-scale emissions and deposition on land and at sea. The dust has a volcanogenic origin of basaltic composition with about $10 \% \mathrm{Fe}$ content. We used two independent methods to quantify dust emission from Iceland and dust deposition at sea. Firstly, the aerial extent (map) of deposition on land was extended to ocean areas around Iceland. Secondly, surveys of the number of dust events over the past decades and calculations of emissions and sea deposition for the dust storms were made. The results show that total emissions range from 30.5 (dust-event-based calculation) to 40.1 million $\mathrm{tyr}^{-1}$ (map calculation), which places Iceland among the most active dust sources on Earth. Ocean deposition ranges between 5.5 (dust event calculations) and 13.8 million tons (map calculation). Calculated iron deposition from Icelandic dust ranges between 0.567 and 1.4 million tons, which are distributed over wide areas $\left(>370000 \mathrm{~km}^{2}\right)$ and consist of fine reactive volcanic materials. The paper provides the first quantitative estimate of total dust emissions and oceanic deposition from Iceland. Iron is a limiting nutrient for primary production in the oceans around Iceland, and the dust is likely to affect Fe levels in Icelandic ocean waters.
\end{abstract}

\section{Introduction}

Dust emissions from barren areas have pronounced influences on Earth's terrestrial and oceanic ecosystems, the atmosphere, climate and human health (Field et al., 2010; Ayris and Delmelle, 2012a). Global estimates of mean annual dust emissions range from 500 to 5000 million tons per year, with most estimates between 1000 and 2000 million tons, but the global oceans are commonly estimated to receive 300-500 million tons (reviewed by Engelstaedter et al., 2006). Dust production is mainly attributed to unstable barren areas in dry climates, with northern Africa being the largest contributor of dust to the atmosphere (Engelstaedter et al., 2006). Other commonly cited dust sources include Mongolia (e.g., Natsagdorj et al., 2003), the Aral Sea basin (Singer et al., 2003), the Middle East (Jamalizadeh et al., 2008), Australia (Ekström et al., 2004; Leys et al., 2011) and the southern USA (e.g., Sweeney et al., 2011). However, dust emissions from the Arctic and Antarctic have received increased attention (Arnalds, 2010; Bullard, 2013; Gillies et al., 2013; Muhs et al., 2013). Research shows frequent dust storms in South Iceland moving into the North Atlantic Ocean (Arnalds and Metúsalemsson, 2004; Prospero et al., 2012) and into the Arctic from Northeast Iceland (Dagsson-Waldhauserova et al., 2013a), and it has been suggested that Iceland is among the world's most active dust sources (Arnalds, 2010; Prospero et al., 2012; Blechschmidt et al., 2012; Bullard, 2013).

Volcanic eruptions have recently become a focus of attention due to possible global nutrient additions to the oceans, including significant iron inputs that are potentially important for primary production (e.g., Duggen et al., 2010; Olgun et al., 2011; Ayris and Delmelle, 2012a). Achterberg et al. (2013) measured significantly elevated iron levels south of Iceland during the 2010 Eyjafjallajökull eruption. Volcanic ash is commonly subjected to intense aeolian redistribution (see Arnalds, 2010, 2013; Ayris and Delmelle, 2012a; 


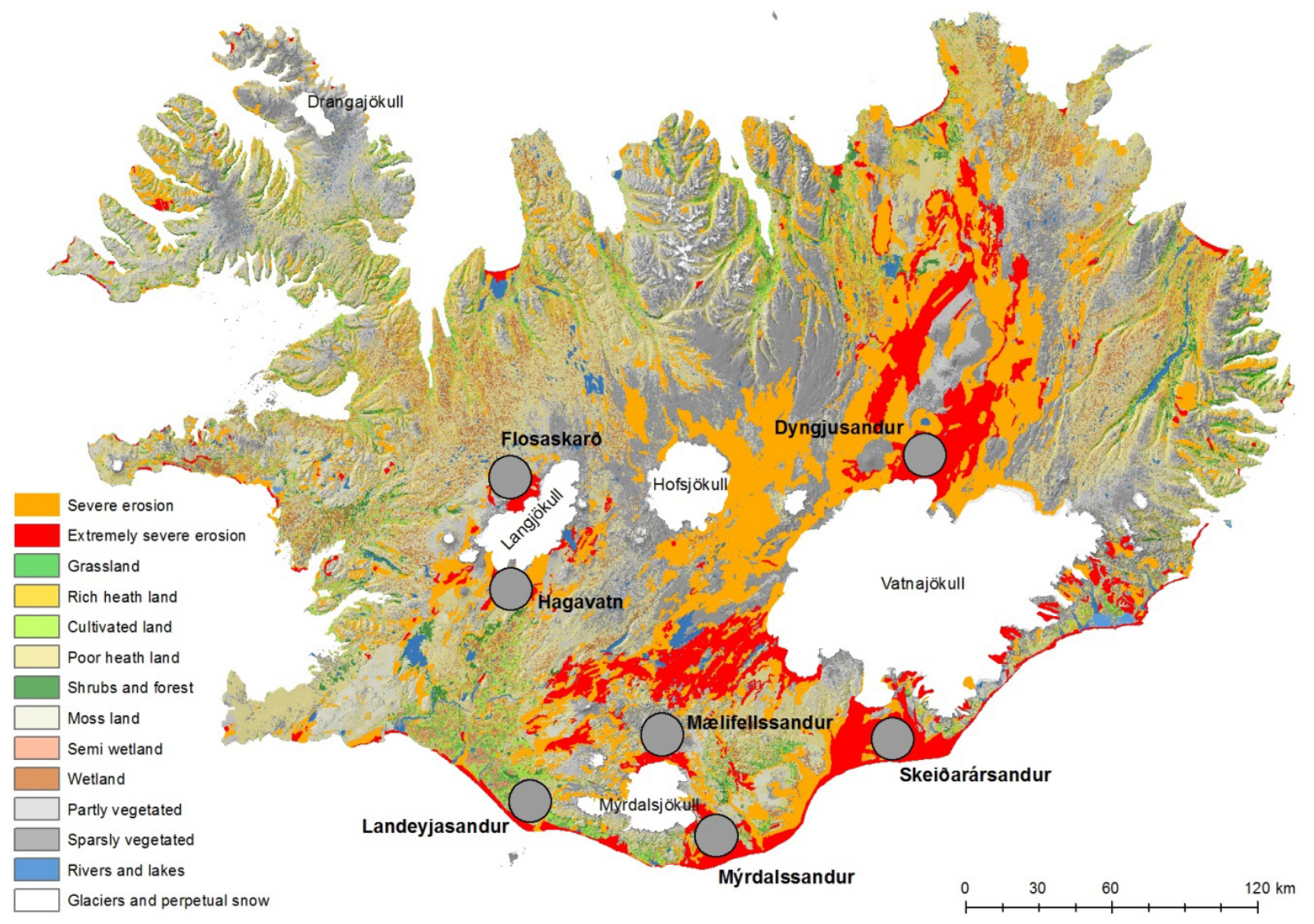

Figure 1. Location of major plume areas in Iceland shown as circles. These plume areas were defined by Arnalds (2010) as areas of excessive frequency of dust events (hence low threshold velocities). Dust was carried vast distances, and the areas are easily identified by scanning and monitoring MODIS images for several years. Sandy areas with unstable surfaces, which also become dust sources during high-intensity winds, are shown as red (very unstable) and orange (unstable). Glaciers are shown as white. The map is based on the Agricultural University of Iceland land cover database.

Bullard, 2013), as was witnessed after the 2010 Eyjafjallajökull eruption (Thorsteinsson et al., 2012). Furthermore, some glaciogenic Arctic dust sources are composed of ironrich volcanic deposits, such as in Iceland (Baratoux et al., 2011; Prospero et al., 2012; Dagsson-Waldhauserova et al., 2013b) and some parts of Alaska (Muhs et al., 2013). In Iceland, these aeolian materials are primarily poorly crystallized basaltic materials (glass) containing high quantities of iron, which can have a substantial impact on the ocean chemistry and fertility. The iron from dust has pronounced effects on the global carbon cycle and atmospheric $\mathrm{CO}_{2}$ (Jickells et al., 2005; Mahowald et al., 2005; Misumi et al., 2014). Schulz et al. (2012) noted that little is known about the mechanics and quantities of dust deposition in the oceans, with large uncertainties regarding the iron contents available for marine phytoplankton.

In spite of the importance for the oceanic nutrient cycles, little is known about how much volcanic material is blown to the oceans around Iceland. Here, we present the first quantitative estimate of the total dust emissions from
Iceland and the first quantitative estimate of aeolian redistribution of the volcanic materials and iron to the ocean areas from Iceland. These estimates are based on: (i) the number of dust events generated from weather records over several decades throughout Iceland; (ii) numerical calculations of selected dust storms; (iii) the modification and extension of established sedimentation rates on land to oceanic areas.

\section{Setting: the Icelandic dust sources}

Iceland is a volcanic island on the active Mid-Atlantic Ridge, with about 30 active volcanic systems and volcanic eruptions occurring every $3-5 \mathrm{yr}$ on average (Thordarson and Höskuldsson, 2008). About $10 \%$ of the country is covered with glaciers, including the $8100 \mathrm{~km}^{2}$ Vatnajökull (Fig. 1). Many active volcanoes are located under the glaciers, including the Katla volcanic system under Mýrdalsjökull, and the Grímsvötn and Bárdarbunga systems under Vatnajökull (Fig. 1). 


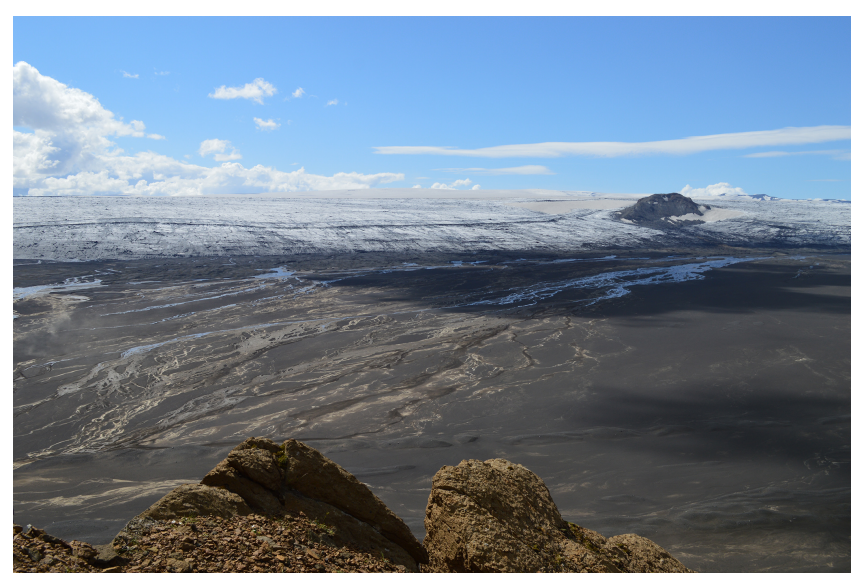

Figure 2. Typical plume area in Iceland: Maelifellssandur, north of Myrdalsjökull. The photo shows approximately $3 \mathrm{~km}$ of the glacial front but the plume area is $>25 \mathrm{~km}^{2}$. The sand fields are flooded during warm summer days, charging the surface with silty materials (lighter colored areas, deposited from higher water flow the previous day or days). Some of the channels dry out as the water percolates into the surface, with the sediment loads being left on the surface. The coarser materials are left on the ground after wind erosion events (saltation, the darker materials). The water channels change frequently. Dust storms are extremely common within this area during summer (often daily), but less frequent during winter when this highland area is usually covered with snow. Photo from July 2012 (Photo: O. Arnalds).

Glacial rivers bring heavy sediment loads, creating extensive glaciofluvial outwash plains in many areas. These plains are often flooded during the summer melt, leaving sediments on the surfaces that are extremely vulnerable to redistribution by wind (Fig. 2). Many of these areas have been identified as major dust plume sources or dust hotspots (Arnalds, 2010). The sandy deserts of Iceland are, however, much larger than these main dust plume sources, about $15000 \mathrm{~km}^{2}$ in all, and most of these areas can emit dust during the highest-intensity dry winds (see Arnalds, 2010). In addition to plume areas (hot spots) and the sandy areas in general, there can be periods of dust generation after the deposition of ash from volcanic eruptions on poorly vegetated and barren land, as witnessed after the 2010 Eyjafjallajökull and 2011 Grímsvötn eruptions (Leadbetter et al., 2012; Arnalds et al., 2013). Furthermore, fluvial outburst events associated with eruptions under glaciers can leave unstable sediments that result in frequent dust events (Prospero et al., 2012).

Most dust emission events in NE Iceland are driven by low sea level pressure (SLP) west of Iceland (and/or high SLP east of Iceland), which leads to warm geostrophic southerly winds. Dust events in S Iceland are generally linked to reserved east-west SLP which turns into cold geostrophic Arctic winds (Björnsson and Jonsson, 2003; Dagsson-Waldhauserova et al., 2013a, b).

\section{Methods}

\subsection{Dust event frequency}

Visibility is an important indicator of dust event severity where dust concentration measurements are not available. The long-term frequency of atmospheric dust observations has been investigated in detail for NE Iceland (DagssonWaldhauserova et al., 2013a) and for the southern part of Iceland (Dagsson-Waldhauserova et al., 2013c) based on present weather observations at 8 weather stations in $\mathrm{NE}$ Iceland, 15 stations in S Iceland and 7 stations in NW Iceland. A dust day was defined as a day when at least one station made at least one dust observation. For this study, we included synoptic codes 04-06 for "Visibility reduced by volcanic ashes", "Dust haze" and "Widespread dust in suspension in the air" in the criteria for dust observation (see Dagsson-Waldhauserova et al., 2013a for details). The most frequent were dust observations of "Suspended" and "Moderate suspended" dust (NE 73\%; S $52 \%$ ), with a visibility of 10-70 km, "Severe" and "Moderate haze" (NE 23\%; S $42 \%$ ), with a visibility of $1-10 \mathrm{~km}$, and "Severe" and "Moderate" dust storm (NE 4\%; S 6\%), with a visibility of less than $1 \mathrm{~km}$. The total number of dust days in Iceland, based on averages presented elsewhere (Dagsson-Waldhauserova et al., 2013a, b), is 135 dust days per year on average in Iceland in 1949-2011. About 34 dust days were observed annually in NE Iceland and about 101 dust days annually in the southern part of Iceland. The storms were divided into three categories based on visibility categories of weather observations (see Dagsson-Waldhauserova et al., 2013a).

\subsection{Calculated dust storm emissions and transport to oceanic areas}

The estimation of dust transport was based on several sources of atmospheric data. A similar methodology has been used to calculate emissions from single storms by Leys et al. (2011). The concentration of dust is based on: (i) the observed visibility at manned weather stations; (ii) the horizontal extension of the dust plumes; and (iii) the repetitiveness of the visibility observations, confirmed by comparing MODIS images of the storms to other typical storms captured by MODIS. The winds in the atmospheric boundary layer were estimated from ground-based and upper-air observations as well as numerical simulation, and the thickness of the boundary layer was estimated from the upper-air observations and numerical simulations. The upper-air observations are made at 00:00 and 12:00 UTC at Keflavik, SW Iceland, and Egilsstaðir, E Iceland. The numerical model, Harmonie (based on Arome model; see Seity et al. (2011)) was run with subgrid 1-D turbulence scheme based on Cuxart et al. (2000), with a horizontal resolution of $2.5 \mathrm{~km}$. The simulations are based on initial and boundary conditions from the operational suite of the ECMWF. The numerical simulations are only used to 
Table 1. Calculation of four storms based on visibility determined at weather stations and wind data for each storm, using equations from D'Almeida (1986) and Wang et al. (2008) converting visibility into PM $_{10}$ concentrations (factor -1.418); see also Dagsson-Waldhauserova et al. (2013). Total emissions calculated by formula given by Leys et al. (2011) and the deposition curve presented in Fig. 4, which reflects drop in concentration. All storms occurred at the Dyngjusandur dust source in NE Iceland. The column "Distance from source" indicates the location of the calculated window through which materials in the last column are transported. "Emissions through window" means how much material is transported through the window (e.g., to the sea).

\begin{tabular}{lcccc}
\hline Storm & Size & $\begin{array}{c}\text { Distance } \\
\text { from source }\end{array}$ & $\begin{array}{c}\text { Total emissions } \\
\text { from source }\end{array}$ & $\begin{array}{c}\text { Emissions } \\
\text { through window }\end{array}$ \\
\hline & & Km & \multicolumn{2}{c}{ thousand tons } \\
\hline 23 Sep 2008 & Medium-large & 90 & 384 & 160 \\
24 Sep 2011 & Medium & 90 & 255 & 110 \\
25 May 2012 & Medium-large & 90 & 365 & 150 \\
9 Aug 2012 & Medium & 155 & 215 & 75 \\
\hline
\end{tabular}

estimate the height of the atmospheric boundary layer and the winds inside the boundary layer.

Four dust storms originating at the Dyngjusandur major dust source north of Vatnajökull (Fig. 1) were selected for the estimation of the total transport of suspended dust. The average duration of the dust storms was $17.3 \mathrm{~h}$. In all four storms, the visibility in the dust plume was observed and recorded, and the vertical, horizontal and temporal extension of the plume was estimated from the available data. For a $1-2 \mathrm{~km}$ thick convective boundary layer the dust can be expected to be quite well mixed vertically after the advection of about $100 \mathrm{~km}$ in $1-2 \mathrm{~h}$. The sea front is located at $200 \mathrm{~km}$ from the dust source in NE Iceland and $140 \mathrm{~km}$ in E Iceland, but the window was calculated as being about $90 \mathrm{~km}$ in a northeasterly direction (three storms) and 155 in an easterly direction (one storm), which is determined by the location of weather stations. The boundary-layer winds are typically $15-23 \mathrm{~m} \mathrm{~s}^{-1}$, and the height of the boundary layer is on the order of $1-2 \mathrm{~km}$. This may sound low, but it should be kept in mind that dust storms occur typically in stable stratified flow and that there is limited heating from the ground due to little solar radiation in Iceland and the short advection time of the air mass over land. The calculated total amount of emitted materials was calculated as $M=C \times U \times Z_{i} \times L \times T$, where $C$ is the dust concentration estimated from visibility, $U$ is the boundary-layer mean wind speed, $Z_{i}$ is the height of the boundary layer, $L$ is the width of the plume where the visibility is observed and $T$ is the duration of the storm. The resulting total amount ranged from 215000 to 384000 tons. Materials transported as dust through the calculated window ranged from 75000-160000 tons in each storm (Table 1).

\subsection{GIS-based dust deposition distribution}

An aeolian deposition map for Iceland was presented by Arnalds in 2010. The map is based on soil metadata showing thicknesses between tephra layers (volcanic ash) of known age, main dry wind directions from each major dust source and landscape parameters downwind from the sources. This deposition illustrated on the map has a close relationship with iron content measured in mosses, which is primarily wind deposited (data and map published by Magnússon, 2013), and with the fertility of ecosystems, as reflected in bird abundance (Gunnarsson et al., 2014), but also with many basic soil parameters such as $\mathrm{pH}$, organic content and clay formation (Arnalds, 2008, 2010). We have extended the map to oceanic areas and included categories for very low deposition furthest away and extreme deposition closest to the aeolian sources. The map (Fig. 3) now shows six broad categories of deposition in $\mathrm{g} \mathrm{m}^{-2} \mathrm{yr}^{-1}$ : (i) very low, 1-15 (added to the previous map of Arnalds, 2010); (ii) low, 10-50; (iii) medium, 25-100; (iv) high, 75-250; (v) very high, 250-500 $\mathrm{g} \mathrm{m}^{-2} \mathrm{yr}^{-1}$ and (vi) extreme, 500-800 $\mathrm{g} \mathrm{m}^{-2} \mathrm{yr}^{-1}$ (added to the previous map). Note that the deposition range for each class overlaps with the next. The highest class (extreme) is expected to receive $>800 \mathrm{~g} \mathrm{~m}^{-2} \mathrm{yr}^{-1}$ at some landscape positions. Mean deposition on glaciers was estimated at $400 \mathrm{~g} \mathrm{~m}^{-2} \mathrm{yr}^{-1}$ based on the deposition map. The aerial distribution of the deposition classes over the sea is in part based on a number of satellite images (MODIS; Aqua and Terra) taken over the past decade. These images show plumes extending several hundred kilometers south into the Atlantic Ocean and northeast into the Arctic Ocean. The major extension to the south reflects the presence of three major dust plume areas on the south coast (Landeyjasandur, Mýrdalssandur and Skeidarársandur; see Arnalds, 2010), which emit frequent and often major dust storms with NE dry winds. These events have repeatedly been captured by MODIS satellite images. We expect that most of the dust settles relatively close to the source, with a logarithmic drop in sedimentation with distance from the source (Fig. 4).

\subsection{Iron content of the dust materials}

The chemical composition of the major sand sources can be determined from published materials. The common range for iron in Icelandic volcanic rocks is 6.5 to $12.5 \%$ with an average about $9.4 \%$, judging from review data presented by 
Table 2. Annual number of dust-day events in South, North and all of Iceland in the second to fourth columns from the left. The dust events are split into three intensity classes, each with calculated average emissions to give total emissions for North and South Iceland. The results are shown as total emissions (land and sea) and emissions over sea (northeast and south of Iceland and total emissions to the sea, last three columns).

\begin{tabular}{|c|c|c|c|c|c|c|c|c|}
\hline Intensity & $\begin{array}{c}\text { Dust events in } \\
\text { NE Iceland per year }\end{array}$ & $\begin{array}{c}\text { Dust events in } \\
\text { S Iceland per year }\end{array}$ & $\begin{array}{l}\text { Total dust events in } \\
\text { Iceland per year }\end{array}$ & $\begin{array}{l}\text { Average emissions } \\
\text { per event }\end{array}$ & $\begin{array}{l}\text { Total deposition, } \\
\text { land and ocean }\end{array}$ & $\begin{array}{l}\text { Emissions to oceans } \\
\text { NE ( } 10 \% \text { of total })\end{array}$ & $\begin{array}{l}\text { Emissions to oceans } \\
\text { S (50\% of total) }\end{array}$ & $\begin{array}{c}\text { Total emissions } \\
\text { to oceans }\end{array}$ \\
\hline & & & & \multicolumn{5}{|c|}{ milion $\mathrm{tyr}^{-1}$} \\
\hline Major & 1.5 & 6.3 & 7.8 & 1 & 7.8 & 0.150 & 3.150 & 3.300 \\
\hline Medium & 7.8 & 42.5 & 50.3 & 0.3 & 15.1 & 0.234 & 1.275 & 1.509 \\
\hline Minor & 25.3 & 52.2 & 75.6 & 0.1 & 7.6 & 0.253 & 0.522 & 0.775 \\
\hline Total & 34.6 & 101 & 135.6 & & 30.5 & 0.637 & 4.917 & 5.554 \\
\hline
\end{tabular}

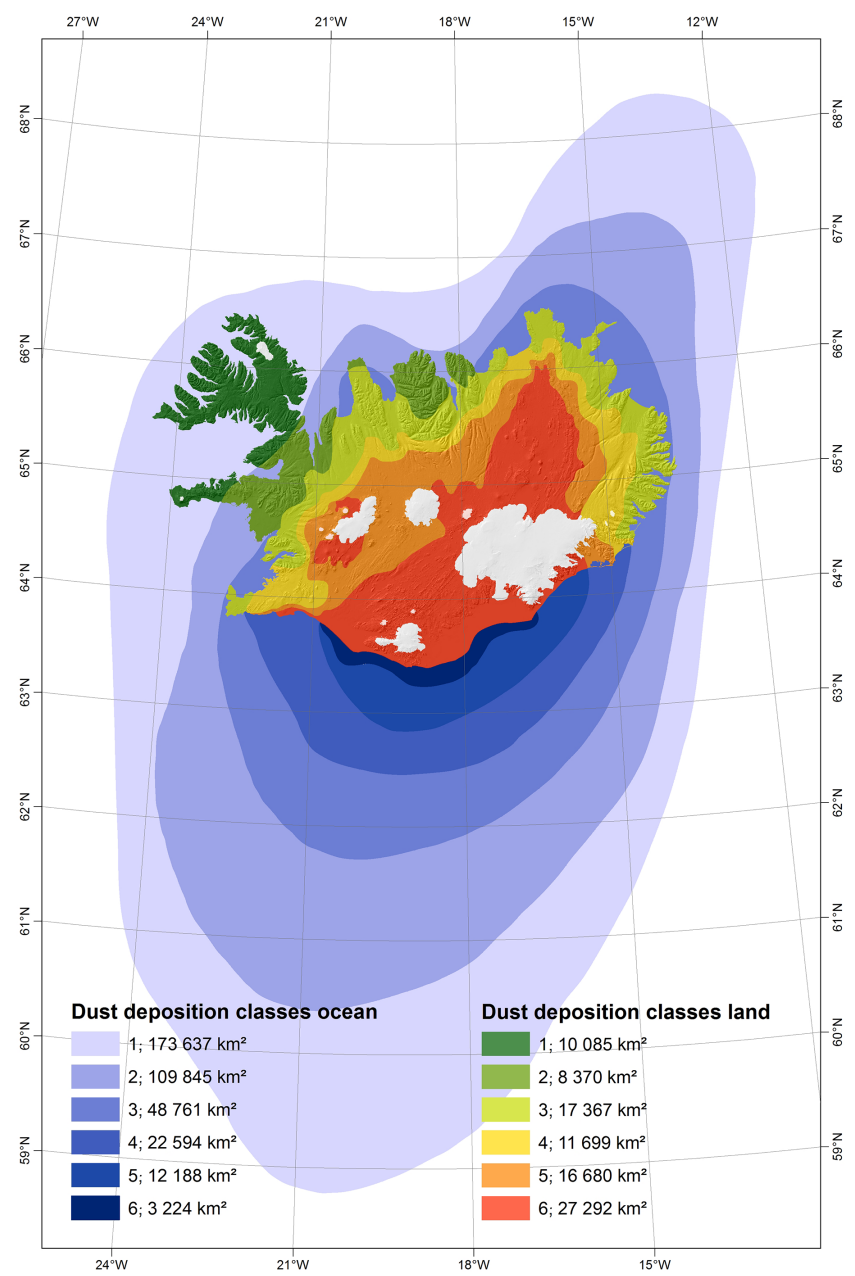

Figure 3. Average distribution of aeolian sediments and volcanic ash around Iceland. Deposition is split into six categories (see map legend) and is an extension of previously published map for terrestrial Iceland (Arnalds, 2010). Extension to sea is partly based on satellite images showing dust storm events. Main extension is to the south from the southern Iceland dust plume areas and to the northeast, mainly from the Dyngjusandur dust plume source (see Sect. 3.3).

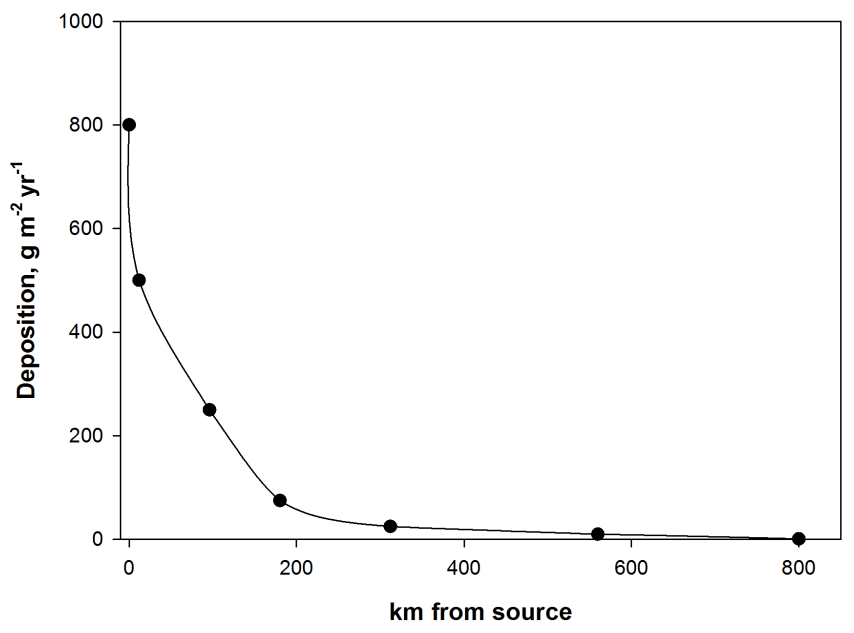

Figure 4. The logarithmic drop in sedimentation with distance from the sediment source. Transect south of the dust sources at the southern tip of Iceland. The transect from Dyngjusandur in NE Iceland has $x$-axis scale approximately divided by 2 .

sandur plume source, the primary dust source in NE Iceland, has $9.4 \%$ Fe content, made of volcanic glass (Baratoux et al., 2011). The Hagavatn plume source has a similar iron content but is made of more crystalline basalt grains (Baratoux et al., 2011). Óladóttir et al. (2011) reported slightly lower Fe content in tephra for volcanic systems under Vatnajökull (Bárdarbunga and Grímsvötn), i.e., 9.2\%, based on a large number of determinations. Tephra from the Katla volcanic system under Mýrdalsjökull has similar but slightly higher $\mathrm{Fe}$ contents, mostly 10-11\% (Óladóttir et al., 2008). The Katla, Grímsvötn systems are responsible for the majority of dust going south from Iceland, which is the majority of the Icelandic oceanic dust. Thus, in this paper we have selected the average of $10 \% \mathrm{Fe}$ in volcanic dust from Iceland.

Jakobsson et al. (2008) (andesite and basalts). The Dyngju- 
Table 3. Deposition on land and sea based on a map of deposition on land (Arnalds 2010) and extension of the data to oceanic areas around Iceland.

\begin{tabular}{|c|c|c|c|c|c|c|}
\hline \multirow[b]{2}{*}{ Category } & \multirow{2}{*}{$\begin{array}{r}\text { Average } \\
\text { Deposition }\end{array}$} & \multicolumn{2}{|c|}{ Areal extent } & \multicolumn{3}{|c|}{ Deposition } \\
\hline & & Land & Ocean & Land & Ocean & Total \\
\hline & $\mathrm{tkm}^{-2}$ & \multicolumn{2}{|c|}{$\mathrm{km}^{2}$} & \multicolumn{3}{|c|}{ million ${\mathrm{t} \mathrm{yr}^{-1}}^{-1}$} \\
\hline 1 & 5 & 10085 & 173637 & 0.05 & 0.89 & 0.92 \\
\hline 2 & 20 & 8370 & 109845 & 0.17 & 2.20 & 2.36 \\
\hline 3 & 44 & 17367 & 48761 & 0.76 & 2.15 & 2.90 \\
\hline 4 & 119 & 11699 & 22594 & 1.39 & 2.69 & 4.08 \\
\hline 5 & 350 & 16680 & 12188 & 5.84 & 4.27 & 10.10 \\
\hline 6 & 500 & 27297 & 3244 & 13.65 & 1.60 & 15.27 \\
\hline Glaciers & 400 & 11185 & & 4.47 & & 4.47 \\
\hline Total & & 102683 & 370269 & 26.33 & 13.79 & 40.11 \\
\hline
\end{tabular}

\section{Results}

\subsection{Dust quantities based on frequency and calculated emissions}

We found that there are 135 dust storm events that occur on average in Iceland each year. However, some storms go unnoticed by weather stations (northerly winds at the Landeyjasandur, Mýrdalssandur and Skeidarársandur and more southeasterly dust sources). The total emissions derived are 30.5 million tons per year over land and sea. The majority is deposited on land ( 25 million tons), while 5.6 million tons are deposited over the sea, mostly from the south shore (Table 2). The emissions per medium storm are about 300000 tons per storm according to these calculations, but "minor" storms of about 100000 tons emissions are most frequent (75.6 annually). The major storm is estimated to give 1 million tons per event, which we consider a conservative estimate, but these storms are relatively infrequent.

The path of dust over land is much longer in NE Iceland, i.e., $130-150 \mathrm{~km}$ from the Dyngjusandur source but shorter from other sandy areas. More is therefore deposited over land in NE Iceland, and we estimate that only $10 \%$ of dust emitted from NE Iceland reaches the oceans, based on the calculations presented in Sect. 3.2, which gave transport through a window at $90-155 \mathrm{~km}$ distance as being on the order of $75000-160000$ tons in each storm (see Table 1). This drop in deposition rates with distance from the source is supported by the drop indicated by the deposition map (see graph in Fig. 4 above), but it is a conservative estimate of the proportion of dust materials reaching the sea in NE Iceland considering dust storm calculations presented in Table 1. Many of the major dust sources of South Iceland are located close to the shoreline (Fig. 1), and we estimate that $50 \%$ of the dust emissions reach oceanic areas, which we consider a conservative estimate.

\subsection{Total deposition on land and sea based on the GIS deposition map}

The results from the calculations of dust deposition on land and oceans around Iceland are presented in Table 3. There is a logarithmic drop in deposition with distance from the source. We used the lower $25 \%$ percentile for deposition within each range, reflecting the logarithmic drop and the aerial increase in size of each category with increasing distance from the sources. The results show that about 40.1 million tons are deposited annually on land, glaciers and sea. This number compares to the 30.5 million tons of total emissions calculated from storm frequency and dust intensity. These results for the total emissions (40.1 vs. 30.5 million tons) are relatively comparable and provide the first estimate of total dust emissions from Icelandic dust sources.

About 14 million tons are deposited on about $370000 \mathrm{~km}^{2}$ ocean area according to the GIS deposition map, but about 26 million tons on about $103000 \mathrm{~km}^{2}$ on land (including glaciers). These map-based deposition values for land and glaciers (26 million tons) are very comparable to the 25 million tons calculated from the number and the severity of storms for land. However, the map calculations indicate a higher (14 million tons) deposition to oceans than the storm calculation method (5.5 million tons).

\subsection{Oceanic iron deposition from Iceland}

The values obtained from the calculations of emissions on the one hand (Sect. 3.1) and deposition based on the GIS map (Sect. 3.2.) on the other give a range for probable rates of deposition to the oceans: 5.5-13.8 million tons. Using these numbers, it can be inferred that the total iron deposition to the oceans (about $1 / 10$ of the weight) is about $0.5-1.4$ million tons in total per year (Table 3). The Fe sediment rates vary immensely from 0.1 to $0.5 \mathrm{~g} \mathrm{~m}^{-2} \mathrm{yr}^{-1}$ for areas far from Iceland to $>13 \mathrm{~g} \mathrm{~m}^{-2} \mathrm{yr}^{-1}$ close to the southern shore. The last column in Table 3 shows an estimate of bioavailable $\mathrm{Fe}$ 
based on evidence presented by Achterberg et al. (2013) after the 2010 Eyjafjallajökull eruption (see Discussion). The bioavailable iron ranges from $0.02-0.1 \mathrm{mg} \mathrm{m}^{-2} \mathrm{yr}^{-1}$ far from the sources to $2.8-10 \mathrm{mg} \mathrm{m}^{-2} \mathrm{yr}^{-1}$ closest to the sources in South Iceland. Maximum numbers of $>50 \mathrm{mg} \mathrm{m}^{-2} \mathrm{yr}^{-1}$ can be expected in localized areas.

\section{Discussion}

\subsection{Total dust emissions from Iceland}

Our research indicates that total emissions of dust from Icelandic dust sources are in the range of 30-40 million tons annually, with the majority of the sediments deposited on land. The two values at each end of this range are obtained by independent methods but are, however, in relatively good agreement. The deposition rates used for obtaining the total emissions from the GIS map are in good agreement with local and regional deposition values reviewed by Lawrence and Neff (2009), especially close to the sources. More uncertainties exist in the values far from the sources, with deposition rates as low as $1 \mathrm{~g} \mathrm{~m}^{-2} \mathrm{yr}^{-1}$ and with a large areal extent. Judging from the difference between the calculated deposition (from the number of events and their severity) and extending the aeolian deposition map, it is likely that deposition on distant sources is somewhat overestimated. Data for deposits on land acquired for the construction of the deposition map are also less reliable for those areas (thin deposits and fewer ash-layer markers).

There are several uncertainties associated with quantifying each of the storms and the amount carried to sea. Horizontal extension of the windstorms and their duration is estimated to be on the order of $10-20 \%$, while the uncertainty of the concentration estimated from horizontal visibility as well as the vertical extension of the dust plumes is estimated to be $30-50 \%$. The uncertainty of the concentration is twofold. Primarily, it is related to uncertainty in the manual estimation of the visibility and how well it represents the entire dust plume. Secondly, observations may deviate from the present cases in terms of particle size distribution and optical properties, which are not known and presumably variable to some extent, even from case to case in Iceland. In short, the error in the estimation of the dust transport for each individual case must be considered to be as high as 50-100\%. Furthermore, the uncertainty in the estimate of how much of emitted materials reaches the sea is unknown. Yet the relatively similar quantities derived for the total emissions and sea emissions compared to values obtained from the deposition maps show that these estimates are adequate as first approximations.

The dust emissions in Iceland presented here (31-40 million tons) are on the order of 0.6-7.2\% of the total estimate for global dust emissions of 500-5000 million tons given in a review by Engelstaedter et al. (2006). They noted that North Africa is by far the largest source of dust with 170-1600 mil- lion tons; our numbers are $1.9-21 \%$ of these estimates of North African dust.

The total oceanic deposition from Iceland ranges between 5.5 and 14 million tons annually, according our results. Engelstaedter et al. (2006) reviewed estimates of mean annual dust depositions to the oceans, which range between 314 and 910 million $\mathrm{tyr}^{-1}$ to the oceans globally and 140 to 260 million $\mathrm{y} \mathrm{yr}^{-1}$ to the North Atlantic Ocean. The North Atlantic estimates are close to values reported in a review by Mahowald et al. (2005), suggesting that the North Atlantic receives about 200 million tons of dust annually, mostly from Africa. The Icelandic dust to oceans amounts to $2.8-7 \%$ of this quantity. The dust deposition per unit area west of the Sahara is considered to be about $10 \mathrm{t} \mathrm{km}^{-2} \mathrm{yr}^{-1}$ (Duce et al., 1991). The corresponding average number from the data presented here is $10.4-25.7 \mathrm{t} \mathrm{km}^{-2} \mathrm{yr}^{-1}$ on average over $370000 \mathrm{~km}^{2}$ sea area, equal to or substantially greater than the rates reported by Duce et al. (1991). It is therefore evident that Icelandic dust sources rate among the globally most active sources, contributing a sizeable share of atmospheric dust to the North Atlantic Ocean and most likely the majority of dust deposits to the northern part of the North Atlantic Ocean and the Atlantic part of the Arctic Ocean (Greenland and Norwegian seas).

\subsection{Oceanic iron deposition with dust}

Jickells et al. (2005) indicated that atmospheric sources of iron were on the order of 16 million tons Fe per year. The Icelandic aeolian sediments are exceptionally iron rich, which explains the high values of deposited iron to Icelandic waters. Iron deposition to oceans from Icelandic sources is on the order 0.56-1.39 million tons (Table 4), which is a sizeable proportion of the estimate of the global total (3.5-8.7\%). However, Jickells et al. (2005) report fluvial (625-962 million t) and glacial sediments (34-211 million tons) as much larger sources for the flux of iron to the oceans, but their spread is naturally considerably more limited and closer to the outlets.

There is evidence that the oceans south of Iceland are $\mathrm{Fe}$ limited during and after peak bloom, and the Irminger Basin waters have been identified as an area of low dissolved $\mathrm{Fe}$ (Nielsdóttir et al., 2009; Ryan-Keogh et al., 2013). Achterberg et al. (2013) found elevated Fe levels in surface waters south of Iceland during the 2010 Eyjafjallajökull eruption, indicating that volcanic activity can raise the oceanic $\mathrm{Fe}$ numbers. They, however, pointed out that the potential positive effect of such nutrient pulses as provided by eruptions depended on other conditions, such as nitrogen availability, and the effects are potentially short-lived. We do, however, concur with Prospero et al. (2012) that the numerous periodic dust plumes over the Icelandic waters can have a prolonged effect on $\mathrm{Fe}$ availability south of Iceland and also in other Icelandic waters. Furthermore, many of the dust storm events occur in spring in South Iceland (March-May), which 
Table 4. Range of annual dust deposition over sea areas from Iceland: total and per unit area, iron deposition and a calculation of bioavailable iron from Icelandic dust ( $0.02 \%$ of total Fe, Achterbert et al., 2013). Range of dust deposition found by (i) frequency determination and dust load calculation (lower values) and (ii) map-based deposition numbers (higher values).

\begin{tabular}{|c|c|c|c|c|c|c|}
\hline & Deposition per year & Sea area & Total dust & $\mathrm{Fe}$ & Total Fe on sea & Bioavailable Fe \\
\hline Dep. categ. & $\mathrm{tkm}^{-2}$ or $\mathrm{g} \mathrm{m}^{-2}$ & $\mathrm{~km}^{2}$ & million $\mathrm{tyr}^{-1}$ & $\mathrm{~g} \mathrm{~m}^{-2} \mathrm{yr}^{-1}$ & thousand tyr ${ }^{-1}$ & $\mathrm{mg} \mathrm{m}^{-2} \mathrm{yr}^{-1}$ \\
\hline 1 & $2-5$ & 173637 & $0.35-0.86$ & $0.2-0.5$ & $35-87$ & $0.04-0.1$ \\
\hline 2 & $8-20$ & 109845 & $0.89-2.2$ & $0.8-2$ & $89-220$ & $0.16-0.4$ \\
\hline 3 & $17-44$ & 48761 & $0.88-2.1$ & $1.7-4.4$ & $87-215$ & $0.36-0.88$ \\
\hline 4 & $48-119$ & 22594 & $1.1-2.7$ & $4.8-11.9$ & $109-269$ & $0.97-2.38$ \\
\hline 5 & $142-350$ & 12188 & $1.7-4.3$ & $14.2-35.0$ & $173-427$ & $2.8-7$ \\
\hline 6 & $203-500$ & 3244 & $0.7-1.6$ & $20.3-50.0$ & $66-162$ & $4.1-10$ \\
\hline Total & & 370269 & $5.6-13.8$ & & $560-1390$ & \\
\hline
\end{tabular}

further enhances possible positive growth effects during early summer.

Only part of the iron in the ash becomes available. Iron solubility has generally been calculated as $1-5 \%$ (see Mahowald et al., 2005), but Buck et al. (2010) reported $9 \pm 5 \%$ sea water solubility for iron in aerosol over oceans. How much of this iron becomes bioavailable is uncertain (Jickells et al., 2005). A range of Fe bioavailability has been reported in the literature (e.g., Ayris and Delmelle, 2012b), with $0.004-0.04 \%$ bioavailability reported by Olgun et al. (2011; see also Ayris and Delmelle, 2012a). Achterberg et al. (2013), studying the 2010 Eyjafjallajökull deposition, indicated that only $0.02 \%$ of the Fe would become bioavailable. We made an effort to quantify bioavailable iron based on $0.02 \%$ bioavailability, which is presented in the last column in Table 4; this shows that bioavailable Fe from dust sources is on the order $0.04->10 \mathrm{mg} \mathrm{m}^{-2} \mathrm{yr}^{-1}$. It should, however, be noted that Jones and Gislason (2008) showed that $7 \mathrm{yr}$ Hekla ash (from the 2000 eruption) released substantially less iron than the freshly deposited ash.

The continuous river and aeolian distribution to the oceanic waters has more stable effects on the nutrient contents of the surface waters than volcanic pulses. Annually, Icelandic rivers bring, on average, about 60-70 million tons of sediments to the ocean on average (research reviewed by Gíslason, 2008) compared to 5.6-14 million tons deposited by aeolian processes. In addition to this mean annual flow, large-scale floods in relation to volcanic activity and the draining of subglacial lakes create temporary pulses of sediment release to the oceans from Iceland (and also often dust pulses). The high river inputs will result in high concentrations near the river outlets, dwarfing the aeolian inputs. However, the river-fed sediments are not as widespread as the aeolian deposition. Furthermore, dust far from the sources is relatively fine-grained material, more reactive than the coarser glaciofluvial sediments, and is more likely to affect nutrient contents, such as Fe, in much of the oceanic waters around Iceland. Iron solubility has been suggested to be higher in areas remote from desert plumes (Baker et al., 2005). How- ever, the effect of particle size, i.e., the small grains being distributed over the oceans, is poorly understood (Ayris and Dalmelle, 2012b). There are published experiments on the solubility of iron from fresh volcanic ash; less is known about the iron solubility in volcanic materials redistributed by aeolian processes, but it is likely to be less than for the fresh volcanic ash, as the readily soluble salts adsorbed onto the fresh ash particles have been washed away (e.g., Duggen et al., 2010).

\section{Implications and conclusions}

We present the first available estimates of total dust emissions from Icelandic dust sources, which are obtained using two independent methods and which yielded 30-40 million tons of dust annually. These figures are significant in relation to global emissions and are likely to have widespread effects on atmospheric conditions in the North Atlantic Ocean and in the Arctic. This dust needs to be considered in climate models for the area and is likely to have an impact on albedos of snow, sea ice and glaciers, thus enhancing snowmelt in Iceland and possibly Greenland and Svalbard.

Our research also presents the first estimate of oceanic dust deposition of volcanic materials from Iceland. The amount is in the range of 5.5-13.8 million tons annually, which is a substantial proportion of the dust deposited in the North Atlantic Ocean and the Arctic, and a large contribution of materials to the ocean surface at northerly latitudes (e.g., $>55^{\circ} \mathrm{N}$ ). The 5.5-13.8 million tons of materials deposited as dust are in addition to the 60-70 million tons that are fluvial (Gíslason, 2008), but the aeolian materials are distributed more evenly and over larger areas than the fluvial sediments. This large amount and distribution, shown in Fig. 4, can be used for improving ocean nutrition models for the ocean waters around Iceland.

The iron content of volcanic dust materials deposited from the Icelandic dust sources is high (10\%). Therefore, the dust is expected to release relatively high concentrations 
of bioavailable iron. This iron release can potentially have a marked influence on the primary productivity in oceans around Iceland and needs to be considered for nutrient budgets for the area. Even though the numbers are substantially lower than the fluvial deposition of suspended materials from Iceland, the extensive spread is potentially just as important a factor. Considering the importance for ocean productivity and fisheries, we suggest that the effect of Icelandic dust plumes on primary production should be investigated in greater detail.

Icelandic glaciers are currently retreating due to climate change (Björnsson and Pálsson, 2008). Dust emissions are likely to increase over the next decades with retreating glaciers as some of the major dust source areas (mainly Dyngjusandur, Maelifellssandur and Myrdalssandur; see Fig. 1) leave behind larger floodplains subjected to intense aeolian redistribution of fine sediments. It is important to increase our understanding of the aeolian nature of these major dust source areas, including loading, erosion processes, deflation, dust generation and other factors.

The amount of dust emissions calculated from the deposition map presented here includes periodic pulses from volcanic eruptions, which may result in lower emissions during average years (without eruptions); this can in part explain the difference between calculated deposition from frequency and emissions of storms compared to estimates from deposition on land. Our results provide a best estimate in a subject area where data of this nature did not exist previously but is needed for an improved understanding of oceanic biochemical cycles, productivity and atmospheric conditions.

Edited by: P. Einarsson

\section{References}

Achterberg, E. P., Moore, C. M., Henson, S. A., Steigenberger, S., Stohl, A., Eckhardt, S., Avendano, L. C., Cassidy, M., Hembury, D., Klar, J. K., Lucas, M. I., Macey, A. I., Marsay, C. M., and Ryan-Keogh, T. J.: Natural iron fertilization by the Eyjafjallajökull volcanic eruption, Geophys. Res. Lett., 40, 921-926, 2013.

Arnalds, O.: Soils of Iceland, Jökull (The Icel. J. Earth Sci.), 58, 409-421, 2008.

Arnalds, O.: Dust sources and deposition of aeolian materials in Iceland, Icel. Agric. Sci., 23, 3-21, 2010.

Arnalds, O.: The influence of volcanic tephra (ash) on ecosystems, Adv. Agron., 121, 331-380, 2013.

Arnalds, O. and Metúsalemsson, S.: Dust emissions from South Iceland October 5, 2004, Náttúrufraedingurinn, 72, 90-92, 2004 (in Icelandic).

Arnalds, O., Thorarinsdottir, E. F., Thorsson, J., DagsonWaldhauserova, P., and Agustsdottir, A. M.: An extreme wind erosion event of the fresh Eyjafjallajökull 2010 volcanic ash, Nature Sci. Rep., 3, 1257, doi:10.1038/srep01257, 2013.

Ayris, P. M. and Delmelle, P.: The immediate environmental effects of tephra emission, Bull. Volcanol., 74, 1905-1936, 2012a.
Ayris, P. M. and Delmelle, P.: Volcanic and atmospheric controls on ash iron solubility: A review, Phys. Chem. Earth, 45/46, 103-112, 2012b.

Baker, A. R., Jickells, T. D., Witt, M., and Linge, K. L.: Trends in the solubility of iron, aluminium, manganese and phosphorus in aerosol collected over the Atlantic Ocean, Mar. Chem., 98, 43-58, 2005.

Baratoux, D., Mangold, N., Arnalds, O., Bardintzeff, J.-M., Platevoet, B., Grégorie, M., and Pinet, P.: Volcanic sands of Iceland - Diverse origins of aeolian sand deposits revealed at Dyngjusandur and Lambahraun, Earth Surf. Proc. Landforms, 36 , 1789-1808, 2011.

Björnsson, H. and Jonsson, T.: Climate and climatic variability at Lake Mývatn. Aquatic Ecol., 38, 129-144, 2003.

Björnsson, H. and Pálsson, F.: Icelandic glaciers, Jökull (Icel. J. Earth Sci.), 58, 365-386, 2008.

Blechschmidt, A.-M., Kristjánsson, J. E., Ólafsson, H., Burkhart, J. F., Hodnebrog, Ø., and Rosenberg, P. D.: Aircraft-based observations and high-resolution simulations of an Icelandic dust storm, Atmos. Chem. Phys., 12, 10649-10666, doi:10.5194/acp12-10649-2012, 2012.

Buck, C. F., Landing, W. M., Resing, J. A., and Measures, C.I.: The solubility and deposition of aerosol Fe and other trace elements in the North Atlantic Ocean: Observations from the A16N CLIVAR/CO2 repeat hydrography section, Mar. Chem., 120, 57-70, 2010.

Bullard, J. E.: Contemporary glacigenic inputs to the dust cycle, Earth Surf. Proc. Landforms, 38, 71-89, 2013.

Cuxart, J., Bougeault, P., and Redelsperger, J. L.: A turbulence scheme allowing for mesoscale and large-eddy simulations, Quart. J. Royal Meteorol. Soc., 126, 1-30, 2000.

D’Almeida, G. A.: A model for Saharan dust transport, J. Clim. Appl. Meteorol. 25, 903-916, 1986.

Dagsson-Waldhauserova, P., Arnalds, O., and Olafsson, H.: Longterm frequency and characteristics of dust storm events in Northeast Iceland (1949-2011), Atmos. Enviro., 77, 117-127, $2013 \mathrm{a}$.

Dagsson-Waldhauserova, P., Arnalds, O., and Olafsson, H.: Long Term Dust Aerosol Production from Natural Sources in Iceland, J. Air Waste Manage. Assoc., 63, doi:10.1080/10962247.2013.805703, 2013b.

Dagsson-Waldhauserova, P., Arnalds, O., and Olafsson, H.: Longterm variability of dust-storms in Iceland, Geophys. Res. Abstr., 15, EGU2013-11578-1, 2013c.

Duce, R. A., Liss, P. S., and Merill, J. T.: The atmospheric input of trace species into the World Ocean, Global Biochem. Cy., 5, 193-259, 1991.

Duggen, S., Olgun, N., Croot, P., Hoffmann, L., Dietze, H., Delmelle, P., and Teschner, C.: The role of airborne volcanic ash for the surface ocean biogeochemical iron-cycle: a review, Biogeosciences, 7, 827-844, doi:10.5194/bg-7-827-2010, 2010.

Ekström, M., McTainsh, G. H., and Chappell, A.: Australian dust storms: temporal trends and relationships with synoptic pressure distributions (1960-99), Int. J. Climatol., 24, 1581-1599, 2004.

Engelstaeter, S., Tegen, I., and Washington, R.: North African dust emissions and transport, Earth-Sci. Rev., 79, 73-100, 2006.

Fields, J. P., Belnap, J., Breshears, D. D., Neff, J. C., Okin, G. S., Whicker, J. J., Painter, T. H., Ravi, S., Reheis, M. C., and Reynolds, R. L: The ecology of dust, Front. Ecol. Envir., 8, 423-430, 2010. 
Gillies, J. A., Nickling, W. G., and Tilson, M.: Frequency, magnitude and characteristics of aeolian sediment transport: McMurdo Dry Valleys, Antarctica, J. Geophys. Res.: Earth Surf., 118, 461-479, doi:10.1029/2012JF002473, 2013.

Gislason, S. R.: Weathering rates in Iceland, Jökull, Icel. J. Earth Sci., 58, 387-408, 2008

Gunnarsson, T. G., Arnalds, O., Appleton, G., Méndez, V., and Gill, J. A.: Ecosystem recharge by volcanic dust drives broad-scale variation in bird abundance. J. Biogeogr., Submitted, 2014.

Jamalizadeh, M. R., Moghaddamnia, A., Piri, J., Arbabi, V., Homayounifar, M., and Shahryari, A.: Dust Storm Prediction Using ANNs Technique (A Case Study: Zabol City), Proc. World Acad. Sci. Engin. Technol., 33, 529-537, 2008.

Jakobsson, S. P., Jónasson, K., and Sigurdsson, I. A.: The three igneous rock series of Iceland, Jökull, Icel. J. Earth Sci., 58, 117-138, 2008.

Jickells, T. D., An, Z. S., Andersen, K. K., Baker, A. R., Berametti, G., Brooks, N., Cao, J. J., Boyd, P. W., Duce, R. A., Hunter, K. A., Kawahata, H., Kubilay, N., LaRoche, J., Liss, P. S., Mahowald, N., Prospero, J. M., Didgwell, A. J., Tegen, I., and Torres, R.: Global iron connections between desert dust, ocean biogeochemistry, and climate, Science, 308, 67-71, 2005.

Jones, M. T. and Gislason, S. R.: Rapid releases of metal salts and nutrients following the deposition of volcanic ash into aqueous environments, Geochim. Cosmochim. Acta, 72, 3661-3680, 2008.

Lawrence, C. R. and Neff, J. C.: The contemporary physical and chemical flux of aeolian dust: A synthesis of direct measurements of dust deposition, Chem. Geol., 267, 46-63, 2009.

Leadbetter, S. J., Hort, M. C., von Löwis, S., Weber, K., and Witham, C. S.: Modeling the resuspension of ash deposited during the eruption of Eyjafjallajökull in spring 2010, J. Geophys. Res., 117, D00U10, doi:10.1029/2011JD016802, 2012.

Leys, J. F., Heidenreich, S. K., Strong, C. L., McTainsh, G. H., and Quigley S.: PM $_{10}$ concentrations and mass transport during "Red Dawn" - Sydney 23 September 2009, Aeol. Res., 3, 227-342, 2011.

Magnússon, S. H.: Heavy metals and sulfur in mosses in Iceland 1990-2010: impact of industry (Pungmálmar og brennisteinn í mosa á Íslandi 1990-2010: áhrif iðjuvera), Icelandic Institute of Natural History Report NÍ-13003, Reykjavik, Iceland, 2013 (in Icelandic)

Mahowald, N. M., Baker, A. R., Bergametti, G., Brooks, N., Duce, R. A., Jickells, T. D., Kubilay, N., Prospero, J. M., and Tegen, I.: Atmospheric global dust cycle and iron inputs to the ocean, Global Biogeochem. Cy., 19, GB4025, doi:10.1029/2004GB002402, 2005.

Misumi, K., Lindsay, K., Moore, J. K., Doney, S. C., Bryan, F. O., Tsumune, D., and Yoshida, Y.: The iron budget in ocean surface waters in the 20th and 21st centuries: projections by the Community Earth System Model version 1, Biogeosciences, 11, 33-55, doi:10.5194/bg-11-33-2014, 2014.

Muhs, D. R., Budahn, J. R., McGeehin, J. P., Bettis III, A. E., Skipp, G., Paces, J. B., and Wheeler, E. A.: Loess origin, transport, and deposition over the past 10,1000 years, Wrangell-St. Elias National Park, Alaska, Aeol. Res., 11, 85-99, 2013.

Natsagdorj, L., Jugder, D., Chung, Y. S.: Analysis of dust storms observed in Mongolia during 1937-1999, Atmos. Environ. 37, 1401-1411, 2003.
Nielsdóttir, M. C., Moore, C. M., Sanders, R., Hinz, D. J., and Achterberg, E. P.: Iron limitation of the postbloom phytoplankton communities in the Iceland Basin, Gobal Biogeochem. Cy., 23, GB3001, doi:10.1029/2008GB003410, 2009.

Óladóttir, B. A., Sigmarsson, O., Larsen, G., and Thordarson, T.: Katla volcano, Iceland: magma composition, dynamics and eruption frequency as recorded by Holocene tephra layers, Bull. Volcanol., 70, 475-493, 2008

Óladóttir, B. A., Sigmarsson, O., Larsen, G., and Devidal, J-L.: Provenance of basaltic tephras from Vatnajökull subglacial volcanoes, Iceland as determined by major- and trace-element analyses, The Holocene, 21, 1037-1048, 2011.

Olgun, N., Duggen, S., Croot, P. L., Delmelle, P., Dietze, H., Schacht, U., Óskarsson, N., Siebe, C., Auer, A., and GrabeSchönberg, D.: Surface ocean iron fertilization: the role of airborne volcanic ash from subduction zone and hot spot volcanoes and related iron fluxes into the Pacific Ocean, Global Biogeochem. Cy., 25, GB4001, doi:10.1029/2009GB003761, 2011.

Prospero, J. M., Bullard, J. E., and Hodgkins, R.: High-latitude dust over the North Atlantic: Inputs from Icelandic proglacial dust storms, Science, 335, 1078-1082, 2012.

Ryan-Keogh, T. J., Macey, A. I., Nielsdottir, M. C., Lucas, M. I., Steigenberger, S. S., Stinchcombe, M. C., Actherberg, E. P., Bibby, T. S., and Moore, C. M.: Spatial and temporal development of phytoplankton iron stress in relation to dynamics in the high-latitude North Atlantic Ocean, Limnol. Oceanogr., 58, 533-545, 2013.

Schulz, M., Prospero, J. M., Baker, A. R., Dentener, F., Ickes, L., Liss, P. S., Mahowald, N. M., Nickovic, S., García-Pando, C. P., Rodríguez, S., Sarin, M., Tegen, I., and Duce, R. A.: Atmospheric transport and deposition of mineral dust to the ocean: Implications for research needs, Environ. Sci. Technol., 56, 10390-10404, 2012.

Seity, Y., Brousseau, P., Malardel, S., Hello, G., Bénard, P., Bouttier, F., Lac, C., and Masson, V.: The AROME-France ConvectiveScale Operational Model. Monthly Weather Rev., 139, 976-991, 2011.

Singer, A., Zobeck, T., Poberzsky, L., and Argaman, E.: The PM20 and PM2.5 dust generation of soils/sediments in the Southern Aral Sea Basin, Uzbekistian, J. Arid Environ., 54, 705-728, 2003.

Sweeney, M. R., McDonald, E. V., and Etyemezian, V.: Quantifying dust emissions from desert landforms, eastern Mojave Desert, USA, Geomorphology, 135, 21-34, 2011.

Thordarson, T. and Höskuldsson, Á.: Postglacial volcanism in Iceland, Jökull (Icel. J. Earth Sci.), 58, 197-228, 2008.

Thorsteinsson, T., Jóhannsson, T., Stohl, A., and Kristiansen, N. I.: High levels of particulate matter in Iceland due to direct ash emissions by the Eyjafjallajökull eruption and resuspension of deposited ash, J. Geophys. Res., 117, B00C05, doi:10.1029/2011JB008756, 2012.

Wang, Y. Q., Zhang, X. Y., Gong, S. L., Zhou, C. H., Hu, X. Q., Liu, H. L., Niu, T., and Yang, Y. Q.: Surface observation of sand and dust storm in East Asia and its application in CUACE/Dust, Atmos. Chem. Phys., 8, 545-553, doi:10.5194/acp-8-545-2008, 2008. 